\title{
Bactericidal Potency of Bioderived Carbon and Calcium Decorated on Synthesized Copper Oxide Nanocomposite from Calotropis gigantea against Primitive Wound Associated Pathogens
}

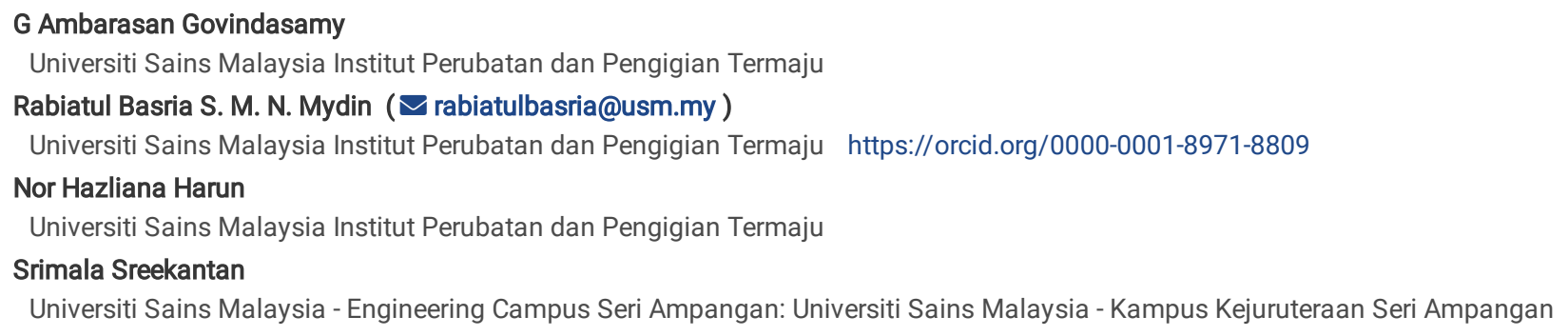

\section{Research}

Keywords: Calotropis gigantea, green synthesis, multi-drug resistant pathogens, wound associated pathogens, antimicrobial agent, bactericidal agent, $\mathrm{CuO} / \mathrm{C} / \mathrm{Ca}$, photocatalytic

Posted Date: February 4th, 2021

DOI: https://doi.org/10.21203/rs.3.rs-166899/v1

License: (a) (i) This work is licensed under a Creative Commons Attribution 4.0 International License. Read Full License 


\section{Abstract}

Commercialized antibiotics are often linked with ineffectiveness in treating chronic wound ulcer especially associated multi-drug resistant pathogens. Photocatalytic nanoparticles have become current trade attention as potent antibacterial agent. This study investigates the bactericidal potency of green synthesised $\mathrm{CuO}$ nanoparticles from Calotropis gigantea (C. gigantea) leaves extract at different calcination temperatures (i.e. $400^{\circ} \mathrm{C}$ and $500{ }^{\circ} \mathrm{C}$ ) against MDR and non-MDR wound related pathogens. A well-defined oval shape $\mathrm{CuO}$ nanoparticles were obtained at $500{ }^{\circ} \mathrm{C}(\mathrm{CuO}-500 \mathrm{C})$ with present of calcium and carbon atoms were characterized using the X-ray powder diffraction, electron microscopy, and energy-dispersive X-ray spectroscopy. FTIR and UV-Vis analysis successfully confirmed phenol and carbonyl group are the stabilizing phytochemical agents. Further antimicrobial performance of CuO-500C sample was observed against non-MDR and MDR pathogens. CuO-500C sample found to markedly inhibit biofilm formation of $S$. aureus. A significant reduction of non-MDR Gram-positive bacterial colonies observe starts from $6 \mathrm{~h}$ exposure and bactericidal activity was noticed at $12 \mathrm{~h}$ exposure. Furthermore, constant prolong free radicals release was observed up to 30 days which might provide advantage against long-term antimicrobial application. Overall, it proves that high concentrated natural carbon and calcium wrapped green synthesised CuO nanocomposite demonstrated potential as a strong antimicrobial agent for combating pathogens associated with open wound infections especially in long- term basis.

\section{Introduction}

Open wound ulcers such as arterial ulcers, chronic ulcers, diabetic foot ulcers, diabetic infections, pressure ulcers, skin disorders, skin infections, surgical wounds, surgical infections, traumatic wounds and venous ulcers are the most common wound injuries leading to human morbidity and mortality including amputation and death [1]. Medicare cost estimates for all wound type's therapies ranged from $\$ 28.1$ to $\$ 96.8$ billion where the highest expenses were for surgical wounds followed by diabetic foot ulcers [1]. It is hardly treatable when the wound is infected by multidrug-resistant (MDR) and non-MDR skin pathogens $[2,3,4]$. Broad-spectrum antibiotics such as vancomycin, oxacillin, penicillin, cefoxitin and chloramphenicol are ineffective to control the growth of MDR skin pathogens and are not preferred in colonized open wound ulcers [5]. Besides of that, non-MDR Gram-positive Staphylococcus aureus (S. aureus) is also one of the most common skin pathogens responsible for the infectious wound ulcers [6]. Of the 137 of wound swab samples studied at University of Gondar Referral Hospital, Northwest Ethiopia, total 136 pathogens were isolated which were mainly consist of Gram-negative (57\%) and Gram-positive (43 $\%$ ) [7]. Recent study showed that, roughly 23,000 deaths a year in the United States (US) and more than 33,000 in Europe recorded due to antibiotics failure in treating MDR strain infected ulcers [8].

Increasing antibiotic resistance has stimulated research addressing green synthesised copper oxide (CuO) with different morphologies as a bactericidal agent to overcome open wound ulcers (Table 1). The rise of green synthesised nanomaterials in biomedical field can be a genuine support in facilitating the healing process of open wound and ultimately repairing the injured tissue. Currently, highly moisturised antimicrobial dressings including those that contain of metals or metal oxides nanoparticles are used locally to manage skin ulcers infection $[40,41,42,43]$. It helps in accelerating the wound recovery process by killing mechanisms of metal ions release and generation of reactive oxygen species (ROS) [14]. Other than that, the calcination temperature had a large effect on physicochemical and antimicrobial properties of metal and metal oxides nanoparticles [44]. In previous studies, F.G. El Desouky et al. (2020) determined that cerium oxide $\left(\mathrm{CeO}_{2}\right)$ crystallite size increases when the calcination temperature is increasing till 500 ${ }^{\circ} \mathrm{C}$ [45] and $\mathrm{Yu}$ et al. (2003) found that higher calcination temperature improves crystallization of the anatase titanium dioxide $\left(\mathrm{TiO}_{2}\right)$ and achieve highest photocatalytic activity at $700^{\circ} \mathrm{C}[46]$. It is also stated by Saravanan et al. (2015) that the high calcinations temperature results in larger average crystalline size of CuO nanoparticles [47]. Moreover, Jiao et al. (2018) identified that poorly crystallized and small grain size of $\mathrm{CuO}$ and $\mathrm{CeO}_{2}$ with high specific surface area (SSA) were obtained for low calcining temperature [48]. 
Table 1

Physicochemical and antimicrobial properties of green synthesised copper oxide (CuO) nanoparticles

\begin{tabular}{|c|c|c|c|c|c|c|c|c|c|}
\hline Precursor & $\begin{array}{l}\text { Reducing/capping } \\
\text { agent }\end{array}$ & $\begin{array}{l}\text { Calcination } \\
\text { temperature }\end{array}$ & $\begin{array}{l}\text { Size } \\
\text { of } \\
\text { NPs } \\
(n m)\end{array}$ & $\begin{array}{l}\text { Shape of } \\
\text { NPs }\end{array}$ & $\begin{array}{l}\text { Antimicrobial } \\
\text { activity }\end{array}$ & $\begin{array}{l}\text { Killing } \\
\text { mechanism }\end{array}$ & Toxicity & Application & Refs \\
\hline $\begin{array}{l}\text { Cupric } \\
\text { Nitrate }\end{array}$ & $\begin{array}{l}\text { Calotropis } \\
\text { gigantea }\end{array}$ & $400^{\circ} \mathrm{C}$ & $\begin{array}{l}20- \\
30\end{array}$ & Spherical & Nil & Nil & Nil & $\begin{array}{l}\text { Dye-sensitized } \\
\text { solar cells }\end{array}$ & [9] \\
\hline $\begin{array}{l}\text { Copper (II) } \\
\text { acetate } \\
\text { monohydrate }\end{array}$ & $\begin{array}{l}\text { Oak Fruit Hull } \\
\text { (Jaft) }\end{array}$ & $500^{\circ} \mathrm{C}$ & Nil & $\begin{array}{l}\text { Quasi- } \\
\text { spherical }\end{array}$ & Nil & Nil & Nil & Photocatalytic & [10] \\
\hline $\begin{array}{l}\text { Copper } \\
\text { nitrate } \\
\text { trihydrate }\end{array}$ & Banana Peel & $400^{\circ} \mathrm{C}$ & $\begin{array}{l}50- \\
85\end{array}$ & Spherical & $\mathrm{Nil}$ & $\mathrm{Nil}$ & Nil & Photocatalytic & [11] \\
\hline $\begin{array}{l}\text { Copper } \\
\text { sulphate } \\
\text { dehydrate }\end{array}$ & $\begin{array}{l}\text { Ocimum } \\
\text { basilicum }\end{array}$ & Nil & 70 & Spherical & $\begin{array}{l}\text { ZOI for } E . \text { coli: } \\
9.8 \mathrm{~mm} \text { and } S . \\
\text { aureus: } 7.2 \mathrm{~mm}\end{array}$ & Copper ions & Nil & $\begin{array}{l}\text { Food and } \\
\text { medical }\end{array}$ & [12] \\
\hline Cupric nitrate & $\begin{array}{l}\text { Gloriosa superba } \\
\text { L. }\end{array}$ & $400^{\circ} \mathrm{C}$ & $5-10$ & Spherical & $\begin{array}{l}\text { ZOI at } 1000 \\
\mu \mathrm{g} / 100 \mu \mathrm{L}: K . \\
\text { aerogenes: } \\
15.67 \mathrm{~mm}, P . \\
\text { desmolyticum: } \\
5.33 \mathrm{~mm}, \mathrm{E} . \\
\text { coli: } 13.67 \mathrm{~mm} \\
\text { and } S . \text { aureus: } 6 \\
\mathrm{~mm}\end{array}$ & Copper ions & Nil & Antibacterial & [13] \\
\hline $\begin{array}{l}\text { Copper (II) } \\
\text { sulphate } \\
\text { pentahydrate }\end{array}$ & Malus Domestica & $\begin{array}{l}\text { Dried under } \\
\text { lamp }\end{array}$ & $\begin{array}{l}18- \\
20\end{array}$ & Spherical & $\begin{array}{l}\text { ZOI at } 100 \\
\mu \mathrm{g} / \mathrm{ml}: \text { E. coli: } \\
17 \mathrm{~mm} \text { and } S \text {. } \\
\text { aureus: } 19 \mathrm{~mm}\end{array}$ & $\begin{array}{l}\mathrm{Cu}^{2+} \text { ion } \\
\text { release, } \\
\text { electrostatic } \\
\text { interaction } \\
\text { and ROS } \\
\text { generation }\end{array}$ & Nil & $\begin{array}{l}\text { Biological } \\
\text { agent }\end{array}$ & [14] \\
\hline $\begin{array}{l}\text { Copper } \\
\text { nitrate }\end{array}$ & Drypetes sepiaria & Nil & $\otimes 18$ & Nil & Nil & Nil & Nil & Photocatalytic & [15] \\
\hline $\begin{array}{l}\text { Copper } \\
\text { nitrate }\end{array}$ & $\begin{array}{l}\text { Catharanthus } \\
\text { Roseus Leaf } \\
\text { Extract }\end{array}$ & $400^{\circ} \mathrm{C}$ & 23 & Nanorod & Nil & Nil & Nil & $\begin{array}{l}\text { Catalytic } \\
\text { material }\end{array}$ & [16] \\
\hline $\begin{array}{l}\text { Copper } \\
\text { sulfate }\end{array}$ & $\begin{array}{l}\text { Phoenix } \\
\text { dactylifera L } \\
\text { extract }\end{array}$ & $400^{\circ} \mathrm{C}$ & $\begin{array}{l}20- \\
28\end{array}$ & $\begin{array}{l}\text { Spherical } \\
\text { and } \\
\text { irregular }\end{array}$ & Nil & Nil & Nil & Nil & [17] \\
\hline \multirow[t]{2}{*}{$\begin{array}{l}\text { Copper } \\
\text { sulfate }\end{array}$} & $\begin{array}{l}\text { Callistemon } \\
\text { viminalis Leaf } \\
\text { Extract }\end{array}$ & $60^{\circ} \mathrm{C}$ & 423 & Nil & $\begin{array}{l}\text { At } 1024 \mu \mathrm{g}: \mathrm{ZOI} \\
\text { for E. coli: } 14 \\
\mathrm{~mm} \text { and }\end{array}$ & Nil & Nil & Nil & [18] \\
\hline & & & & & $\begin{array}{l}\text { A. baumannii: } \\
12 \mathrm{~mm}\end{array}$ & & & & \\
\hline $\begin{array}{l}\mathrm{Cu} \\
\left(\mathrm{NO}_{3}\right)_{2} \cdot 3 \mathrm{H}_{2} \mathrm{O}\end{array}$ & $\begin{array}{l}\text { Tinospora crispa } \\
\text { leaves extract }\end{array}$ & $450^{\circ} \mathrm{C}$ & $\begin{array}{l}10- \\
40\end{array}$ & Spherical & Nil & Nil & Nil & Photocatalysts & [19] \\
\hline $\begin{array}{l}\mathrm{Cu} \\
\left(\mathrm{NO}_{3}\right)_{2} \cdot 3 \mathrm{H}_{2} \mathrm{O}\end{array}$ & $\begin{array}{l}\text { Abutilon indicum } \\
\text { leaf extract }\end{array}$ & $400^{\circ} \mathrm{C}$ & 16.78 & Spherical & $\begin{array}{l}\text { S. aureus, } \\
\text { Klebsiella and } \\
\text { B. subtilis with } \\
\text { ZOl of } 10 \mathrm{~mm}, \\
14 \mathrm{~mm} \text { and } 15 \\
\mathrm{~mm}\end{array}$ & Copper ions & Nil & $\begin{array}{l}\text { Photo-catalytic, } \\
\text { antimicrobial } \\
\text { and antioxidant }\end{array}$ & [20] \\
\hline $\begin{array}{l}\text { Copper } \\
\text { sulfate }\end{array}$ & $\begin{array}{l}\text { Lemongrass Leaf } \\
\text { extract }\end{array}$ & Nil & $\begin{array}{l}5.67- \\
9.10\end{array}$ & Spherical & Nil & Nil & Nil & Photocatalysts & [21] \\
\hline $\mathrm{CuSO}_{4} \cdot 5 \mathrm{H}_{2} \mathrm{O}$ & $\begin{array}{l}\text { Momordica } \\
\text { charantia fruit } \\
\text { extract }\end{array}$ & Nil & 61.48 & Nanorod & $\begin{array}{l}\text { ZOI for } B \text {. } \\
\text { cereus: } 31.66 \\
\mathrm{~mm}\end{array}$ & Copper ions & Nil & Biomedical & [22] \\
\hline $\begin{array}{l}\text { Copper } \\
\text { acetate } \\
\text { monohydrate }\end{array}$ & $\begin{array}{l}\text { Psidium guajava } \\
\text { leaf extract }\end{array}$ & $400^{\circ} \mathrm{C}$ & $2-6$ & Spherical & Nil & Nil & Nil & Photocatalysts & [23] \\
\hline $\begin{array}{l}\text { Copper } \\
\text { sulfate }\end{array}$ & $\begin{array}{l}\text { Adiantum } \\
\text { lunulatum whole } \\
\text { plant extract }\end{array}$ & Nil & 6.5 & Spherical & Nil & Nil & Nil & Nil & [24] \\
\hline
\end{tabular}




\begin{tabular}{|c|c|c|c|c|c|c|c|c|c|}
\hline Precursor & $\begin{array}{l}\text { Reducing/capping } \\
\text { agent }\end{array}$ & $\begin{array}{l}\text { Calcination } \\
\text { temperature }\end{array}$ & $\begin{array}{l}\text { Size } \\
\text { of } \\
\text { NPs } \\
(n m)\end{array}$ & $\begin{array}{l}\text { Shape of } \\
\text { NPs }\end{array}$ & $\begin{array}{l}\text { Antimicrobial } \\
\text { activity }\end{array}$ & $\begin{array}{l}\text { Killing } \\
\text { mechanism }\end{array}$ & Toxicity & Application & Refs \\
\hline Cupric nitrate & $\begin{array}{l}\text { Plectranthus } \\
\text { amboinicus } \\
\text { leaves extract }\end{array}$ & $450^{\circ} \mathrm{C}$ & $5-30$ & $\begin{array}{l}\text { Spherical } \\
\text { and } \\
\text { circular }\end{array}$ & $\begin{array}{l}\text { ZOI for E. coli: } \\
13.65 \mathrm{~mm}, K \text {. } \\
\text { pheumoniae: } \\
13.40 \mathrm{~mm}, P \text {. } \\
\text { aeruginosa: } \\
13.05 \mathrm{~mm} \text {, } \\
\text { S. aureus: } 13.25 \\
\mathrm{~mm}, S \text {. } \\
\text { phogenes: } \\
12.55 \mathrm{~mm} \text {, and } \\
\text { B. Subtilis: } \\
12.80 \mathrm{~mm}\end{array}$ & $\begin{array}{l}\mathrm{Cu}^{2+}, \\
\mathrm{OH}^{-} \text {radicals, } \\
\mathrm{O}_{2}^{2-} \text { ions } \\
\text { and } \\
\text { hydrogen } \\
\text { peroxide } \\
\left(\mathrm{H}_{2} \mathrm{O}_{2}\right)\end{array}$ & Nil & Drug & [25] \\
\hline $\begin{array}{l}\text { Hydrated } \\
\text { copper } \\
\text { chloride }\end{array}$ & $\begin{array}{l}\text { Saraca indica } \\
\text { Leaves }\end{array}$ & $100^{\circ} \mathrm{C}$ & $\begin{array}{l}40- \\
70\end{array}$ & Spherical & Nil & Nil & $\mathrm{Nil}$ & $\begin{array}{l}\text { Fluorescence } \\
\text { emitting } \\
\text { materials }\end{array}$ & [26] \\
\hline $\begin{array}{l}\text { Copper } \\
\text { sulfate }\end{array}$ & $\begin{array}{l}\text { Cassia auriculata } \\
\text { leaf extract }\end{array}$ & Nil & 23 & Spherical & Nil & Nil & $\begin{array}{l}\text { RAW } 264.7 \\
\text { cell lines: } \\
\text { low } \\
\text { cytotoxicity } \\
\text { up to } 200 \\
\mu \mathrm{g} / \mathrm{mL}\end{array}$ & $\begin{array}{l}\text { Drug delivery } \\
\text { vehicle }\end{array}$ & [27] \\
\hline $\begin{array}{l}\text { Copper } \\
\text { nitrate }\end{array}$ & $\begin{array}{l}\text { Juglans regia leaf } \\
\text { extract }\end{array}$ & $\begin{array}{l}300 \text { to } \\
500^{\circ} \mathrm{C}\end{array}$ & 80 & Spherical & $\begin{array}{l}\text { MIC value of } \\
1.78 \% \mathrm{w} / \mathrm{v}\end{array}$ & $\begin{array}{l}\text { Particles } \\
\text { attachment }\end{array}$ & $\mathrm{Nil}$ & $\begin{array}{l}\text { Medicine and } \\
\text { food packaging }\end{array}$ & [28] \\
\hline $\begin{array}{l}\text { Copper } \\
\text { sulfate }\end{array}$ & $\begin{array}{l}\text { Phyllanthus } \\
\text { Amarus leaf } \\
\text { extract }\end{array}$ & Nil & 20 & $\begin{array}{l}\text { Large } \\
\text { aggregated } \\
\text { particles }\end{array}$ & $\begin{array}{l}\text { ZOI for } B \text {. } \\
\text { subtilis: } 31 \mathrm{~mm} \text {, } \\
\text { S. aureus: } 28 \\
\mathrm{~mm}, \text { E. coli: } 24 \\
\mathrm{~mm} \text { and } P \text {. } \\
\text { aeruginosa: } 25 \\
\mathrm{~mm}\end{array}$ & $\begin{array}{l}\text { Amines and } \\
\text { carboxyl } \\
\text { groups }\end{array}$ & $\mathrm{Nil}$ & Nil & [29] \\
\hline $\begin{array}{l}\text { Copper } \\
\text { nitrate }\end{array}$ & $\begin{array}{l}\text { Aloe vera leaf } \\
\text { extract }\end{array}$ & Nil & $\begin{array}{l}20- \\
30\end{array}$ & Spherical & $\begin{array}{l}\text { At } 100 \mu \mathrm{g}: \mathrm{ZOI} \\
\text { for } A \text {. } \\
\text { hydrophila: } 22 \\
\text { mm, } P \\
\text { Fluorescens: } 19 \\
\text { mm and } F \\
\text { branchiophilum: } \\
17 \mathrm{~mm}\end{array}$ & Copper ions & Nil & $\begin{array}{l}\text { Antimicrobial } \\
\text { agents }\end{array}$ & [30] \\
\hline $\begin{array}{l}\text { Copper } \\
\text { chloride salt }\end{array}$ & $\begin{array}{l}\text { Calotropis } \\
\text { gigantea floral } \\
\text { extract }\end{array}$ & Nil & $\begin{array}{l}25- \\
35\end{array}$ & Spherical & Nil & Nil & $\begin{array}{l}\text { Zebrafish } \\
\text { embryos: } \\
50 \% \\
\text { viability } \\
\text { rate for } 50 \\
\text { mg/l }\end{array}$ & Nil & [31] \\
\hline $\begin{array}{l}\text { Copper } \\
\text { sulfate }\end{array}$ & $\begin{array}{l}\text { Convolvulus } \\
\text { percicus L. leaves }\end{array}$ & $400^{\circ} \mathrm{C}$ & $\begin{array}{l}15- \\
30\end{array}$ & Spherical & $\begin{array}{l}\text { MIC for } S . \\
\text { aureus: } 1.56 \\
\text { and } E \text {. coli: } 6.25 \\
\mu \mathrm{g} / \mathrm{ml}\end{array}$ & $\begin{array}{l}\text { ROS } \\
\text { generation }\end{array}$ & Nil & Catalysts & [32] \\
\hline $\begin{array}{l}\text { Copper (II) } \\
\text { acetate }\end{array}$ & $\begin{array}{l}\text { Lantana camara } \\
\text { flower extract }\end{array}$ & $400^{\circ} \mathrm{C}$ & $\begin{array}{l}15- \\
40\end{array}$ & Spherical & Nil & $\mathrm{Nil}$ & Nil & Catalysts & [33] \\
\hline $\begin{array}{l}\mathrm{Cu} \\
\left(\mathrm{CO}_{2} \mathrm{CH}_{3}\right)_{2} \\
\cdot \mathrm{H}_{2} \mathrm{O}\end{array}$ & $\begin{array}{l}\text { Azadirachta } \\
\text { indica leaf extract }\end{array}$ & $400^{\circ} \mathrm{C}$ & 40 & Spherical & Nil & $\mathrm{Nil}$ & Nil & Nutritive agent & [34] \\
\hline $\begin{array}{l}\text { Copper } \\
\text { nitrate } \\
\text { trihydrate }\end{array}$ & Black tea extract & $\begin{array}{l}500,600 \\
700 \text { and } \\
800^{\circ} \mathrm{C}\end{array}$ & $\begin{array}{l}22- \\
39\end{array}$ & Spherical & Nil & Nil & Nil & Nil & [35] \\
\hline $\begin{array}{l}\text { Copper } \\
\text { acetate }\end{array}$ & $\begin{array}{l}\text { Magnolia } \\
\text { champaca floral } \\
\text { extract }\end{array}$ & $60^{\circ} \mathrm{C}$ & $\begin{array}{l}20- \\
40\end{array}$ & Spherical & Nil & Nil & $\begin{array}{l}\text { Zebrafish } \\
\text { embryonic: } \\
90 \% \text { and } \\
60 \% \\
\text { viability } \\
\text { rate for } \\
350 \mathrm{mg} / \mathrm{l} \\
\text { and } 750 \\
\mathrm{mg} / \mathrm{l}\end{array}$ & Nil & [36] \\
\hline
\end{tabular}




\begin{tabular}{|c|c|c|c|c|c|c|c|c|c|}
\hline Precursor & $\begin{array}{l}\text { Reducing/capping } \\
\text { agent }\end{array}$ & $\begin{array}{l}\text { Calcination } \\
\text { temperature }\end{array}$ & $\begin{array}{l}\text { Size } \\
\text { of } \\
\text { NPs } \\
(n m)\end{array}$ & $\begin{array}{l}\text { Shape of } \\
\text { NPs }\end{array}$ & $\begin{array}{l}\text { Antimicrobial } \\
\text { activity }\end{array}$ & $\begin{array}{l}\text { Killing } \\
\text { mechanism }\end{array}$ & Toxicity & Application & Refs \\
\hline $\begin{array}{l}\text { Cupric nitrate } \\
\text { trihydrate }\end{array}$ & $\begin{array}{l}\text { Caesalpinia } \\
\text { bonducella seed } \\
\text { extract }\end{array}$ & $450^{\circ} \mathrm{C}$ & Nil & Rice & $\begin{array}{l}\text { ZOI for } S . \\
\text { aureus: } 25 \mathrm{~mm} \\
\text { and } \\
\text { Aeromonas: } 34 \\
\mathrm{~mm}\end{array}$ & $\begin{array}{l}\text { ROS } \\
\text { generation } \\
\text { and } \\
\text { particles } \\
\text { interaction }\end{array}$ & Nil & $\begin{array}{l}\text { Electrochemical } \\
\text { and biological }\end{array}$ & [37] \\
\hline $\begin{array}{l}\text { Copper } \\
\text { sulphate } \\
\text { pentahydrate }\end{array}$ & $\begin{array}{l}\text { Melia azedarach } \\
\text { leaf extract }\end{array}$ & $80^{\circ} \mathrm{C}$ & $\begin{array}{l}14- \\
20\end{array}$ & Nil & $\begin{array}{l}\text { ZOI for } E \text {. coli: } \\
16 \text { mm, } P . \\
\text { mirabilis: } 4 \mathrm{~mm} \text {, } \\
\text { Salmonella: } 11 \\
\text { mm and } C . \\
\text { tetani: } 7 \mathrm{~mm}\end{array}$ & Nil & Nil & Nil & [38] \\
\hline $\begin{array}{l}\text { Copper } \\
\text { sulphate } \\
\text { pentahydrate }\end{array}$ & $\begin{array}{l}\text { Morus nigra leaf } \\
\text { extract }\end{array}$ & $80^{\circ} \mathrm{C}$ & $\begin{array}{l}14- \\
20\end{array}$ & $\mathrm{Nil}$ & $\begin{array}{l}\text { ZOI for E. coli: } \\
12 \mathrm{~mm}, P . \\
\text { mirabilis: } 13 \\
\text { mm, } \\
\text { Salmonella: } 12 \\
\text { mm and } C \text {. } \\
\text { tetani: } 6 \mathrm{~mm}\end{array}$ & $\mathrm{Nil}$ & Nil & Nil & [38] \\
\hline $\begin{array}{l}\text { Copper } \\
\text { sulfate }\end{array}$ & $\begin{array}{l}\text { Cymbopogon } \\
\text { citratus (CLE) leaf } \\
\text { extract }\end{array}$ & $80^{\circ} \mathrm{C}$ & $\begin{array}{l}11.4- \\
14.5\end{array}$ & $\begin{array}{l}\text { Spherical, } \\
\text { hexagonal } \\
\text { and oval }\end{array}$ & $\begin{array}{l}\text { Survival rate of } \\
\text { S. aureus-1 } \\
\text { (MRSA-1): } \\
51.4 \% \text { at } 1500 \\
\mu \mathrm{g} / \mathrm{mL}, S \text {. } \\
\text { aureus-2 } \\
\text { (MSSA-2): } \\
32.41 \% \text { at } 1500 \\
\mu \mathrm{g} / \mathrm{mL} \text { and } E \text {. } \\
\text { coli-336: } \\
45.27 \% \text { at } 1000 \\
\mu \mathrm{g} / \mathrm{mL}\end{array}$ & Copper ions & Nil & Biomedical & [39] \\
\hline
\end{tabular}

Therefore, the goal of this work is to present an alternative of simple and low-cost green synthesis for the rapid one-step fabrication of highly pure and efficient $\mathrm{CuO} / \mathrm{C} / \mathrm{Ca}$ nanocomposites by aqueous extract of medicinal plant Calotropis gigantea ( $C$. gigantea). The traditional remedies of $C$. gigantea medicinal plant in treating open wound ulcers was well documented [9]. The physicochemical properties of different calcined CuO samples were studied. Additionally, the antimicrobial properties of the $\mathrm{CuO}$ samples were tested against non-MDR and MDR pathogens.

\section{Materials And Methods}

\subsection{Preparation and characterization of green synthesised CuO/C/Ca nanocomposite}

Copper (II) Nitrate Trihydrate (Merck) was used as precursor for green synthesis of CuO nanocomposite. The non-MDR and MDR pathogens of S. aureus 29213, E. coli 25922, P. aeruginosa 27853, K. pneumoniae 700603 and MRSA 38591 were obtained from American Type Culture Collection (ATCC). Methylene blue (Merck) was used for photocatalytic experiment. The fresh leaves of $C$. gigantea plant were collected from Perai Pulau Pinang, Malaysia. The species was authenticated by the expert of Unit Herbarium, Pusat Pengajian Sains Kajihayat USM Pulau Pinang. (Herbarium No.: 11843). Green CuO nanoparticles were synthesized according to the following procedures $[9,49]$. Copper (II) Nitrate Trihydrate was dissolved in filtered $C$. gigantea leaves extracts at boiling temperature of $60-80^{\circ} \mathrm{C}$. The black colored powder samples which annealed at $400^{\circ} \mathrm{C}$ and $500^{\circ} \mathrm{C}$ were denoted as $\mathrm{CuO}-400 \mathrm{C}$ and $\mathrm{CuO}-$ $500 \mathrm{C}$, respectively. X-ray diffraction (XRD) patterns of $\mathrm{CuO}$ nanoparticles and powdered $C$. gigantea leaves were recorded with X-ray diffractometer (Bruker D8) by operating in reflection mode with a Cu Ka radiation $(40 \mathrm{kV}, 30 \mathrm{~mA})$ diffracted beam monochromator, using a step scan mode with step size of $0.030^{\circ}$ in the range of $10^{\circ}$ to $90^{\circ}$. Average crystallite sizes of CuO nanoparticles were obtained using Debye-Scherrer Equation [1]:

$$
d=\frac{K \lambda}{\beta \cos \theta^{\prime}}-\text { Equation } 1
$$

where $\mathrm{K}=0.9$ is the shape factor, $\lambda$ is the $\mathrm{X}$-ray wavelength of $\mathrm{Cu} \mathrm{Ka}$ radiation $(0.1541 \mathrm{~nm}), \theta$ is the Bragg diffraction angle, and $\beta$ is the FWHM of the respective diffraction peak. Scanning electron microscopy (SEM Fei Quanta FEG 650) and transmission electron microscopy (TEM FEI TECHNAI F20 G2) were used for the morphology and microstructure observation of the green CuO nanoparticles, respectively. Semi-quantitative analysis of nanoparticles was carried out by energy-dispersive X-ray spectroscopy (EDAX) which is equipped with SEM machine. The primary detection of CuO nanoparticles and natural compound of leaves extract such as carbonyl and phenol group were investigated using UV-Vis spectrophotometer (Varian) at room temperature in the range of 200-700 nm. The functional groups involved in green synthesis and stabilization of CuO nanoparticles were examined using FTIR spectroscopy (Perkin Elmer). The FT-IR spectra of the green samples were recorded in the range of $4000-400 \mathrm{~cm}^{-1}$ by the $\mathrm{KBr}$ pellet method.

\subsection{Minimum inhibitory concentration/minimum bactericidal concentration}


The MIC/MBC of $\mathrm{CuO}$ nanoparticles were defined by broth dilution method on 96-well plates [50]. The MIC absorbance reading at $980 \mathrm{~nm}$ for CuO wavelengths was recorded before and after $24 \mathrm{~h}$ incubation. Besides, the MIC/MBC at concentration between $10 \mathrm{mg} / \mathrm{mL}$ and $20 \mathrm{mg} / \mathrm{mL}$ for commercial CuO and green $\mathrm{CuO}-500 \mathrm{C}$ samples were investigated under visible light condition. The tolerance levels against green CuO nanoparticles was determined by using the stated formula:

Tolerance $=\mathrm{MBC} / \mathrm{MIC}$

\subsection{Time-kill assay}

The antimicrobial performance of green Cu0-500 $\mathrm{C}$ sample against time was evaluated according to the following time-kill assay method [50]. The adjusted S. aureus bacterial suspension to $0.5 \mathrm{McFarland}$ standard turbidity was used and diluted with $\mathrm{CuO}$ solution with final concentration of $20 \mathrm{mg} / \mathrm{mL}$.

\subsection{Assessment of biofilm formation}

The biofilm mass of $S$. aureus bacterial strain treated with $20 \mathrm{mg} / \mathrm{mL}$ of CuO-500C sample was evaluated by crystal violet staining assay as described by NH Harun et al. (2020) [50].

\subsection{Kirby-Bauer disc diffusion assay}

Antibacterial activity of green $\mathrm{CuO}$ nanoparticles and commercial $\mathrm{CuO}(<10 \mu \mathrm{m}$, Sigma Aldrich) were evaluated against $S$. aureus using disk-diffusion susceptibility test according to the CLSI MO2-A11 (Clinical and Laboratory Standard Institute MO2-A11) guideline [51]. Subsequently, 2.5 mg/mL and 10 $\mathrm{mg} / \mathrm{mL}$ sample's solution were prepared for antibacterial studies. Oxoid ${ }^{\mathrm{TM}}$ Cefoxitin antimicrobial susceptibility disk with concentration of $30 \mu \mathrm{g}$ was introduced as a positive control.

\subsection{Determination of photocatalytic activity}

The photocatalytic activity of green synthesised CuO-500C nanoparticles was studied by degradation of methylene blue (MB) aqueous solution [52]. In brief, about $100 \mathrm{mg}$ of nanoparticles was immersed in $10 \mathrm{ppm}$ of $40 \mathrm{~mL}$ of $\mathrm{MB}$ and kept in dark for a while to attain an equilibrium adsorption state.

Photodegradation efficiency of CuO-500C nanoparticles was evaluated under normal room temperature condition between 1 hour and 1 month. The catalytic degradation of MB was observed by measuring UV-Visible spectra at regular time intervals.

\section{Results And Discussion}

\subsection{Characterization of the green synthesised $\mathrm{CuO} / \mathrm{C} / \mathrm{Ca}$ nanocomposite}

The morphology of the green CuO nanoparticles was studied using scanning electron microscopy and transmission electron microscopy (Fig. 1(e), Fig. 1(f) and Table 2). The SEM images (Figs. 1(a) and (c)) show that the CuO-400C sample have mixture of rod and quasi-spherical shaped nanoparticles and that Cu0-500 sample are mainly oval in shape with agglomerated nano-sized morphology. A histogram showing the particle size of distribution for CuO-500 C nanoparticles which mainly fall between 20 and $22 \mathrm{~nm}$ (Fig. 1(h)). Figure 1(g) shows the TEM lattice fringes with distance of $0.254 \mathrm{~nm}$ for CuO-500C nanoparticles. It was found that rod-shaped microstructures resulted in a slight decrease in the cidal properties against $S$. aureus which is further explained in detail on antimicrobial investigation part (figure S1). It is due to the reduced available SSA. Whereas, oval structures can increase the available SSA for improved antimicrobial reaction. In this step, energy-dispersive spectroscopy (EDAX) analysis was used to evaluate the chemical composition and the purity of the prepared samples. The EDAX profile of the green-synthesised CuO confirms the presence of $\mathrm{Cu}$ and 0 , which are about $17.52 \mathrm{wt.} \%$ and $17.92 \mathrm{wt} \%$, respectively, in CuO-400C and 67.23 wt.\% and 25.05 wt.\%, respectively, in CuO-500C (Figs. 1(b) and (d)). The EDAX profile of CuO exhibits a strong signal for $\mathrm{Cu}$ and $\mathrm{O}$ atoms. Some weak peaks for $\mathrm{C}, \mathrm{Ca}, \mathrm{S}, \mathrm{Cl}, \mathrm{K}$ and $\mathrm{Mg}$ atoms are seen for $\mathrm{CuO}$ green nanoparticles indicates the participation of $\mathrm{C}$. gigantea leaves extract phytochemical compounds during the green synthesis. The $\mathrm{CuO}$ nanoparticles are well encapsulated by $C$. gigantea leaf extract (Fig. 1 (a)), and this similar phenomenon is reported in previous research, where Au nanoparticles are well dispersed in G. mangostana peel extract [53].

Table 2

CuO nanoparticles size and shape

\begin{tabular}{|llll|}
\hline Sample & XRD crystallite size $(\mathbf{n m})$ & $\begin{array}{l}\text { Average TEM size } \\
(\mathrm{nm})\end{array}$ & TEM shape \\
\hline CuO-400C & 24.1 & Rod = Length: 58.46, width: 24.13 ; quasi-spherical: 9.73 & Rod and quasi-spherical \\
\hline Cu0-500C & 24.1 & Diameter: 25.48, length: 21.25 & Oval \\
\hline
\end{tabular}

Diffraction peaks with Miller indices of CuO-400C and CuO-500C samples are presented in Fig. 2(a). CuO-400C and CuO-500C are observed with 12 characteristic peaks at $32.32^{\circ}, 35.50^{\circ}, 38.71^{\circ}, 45.01^{\circ}, 48.37^{\circ}, 53.29^{\circ}, 58.15^{\circ}, 61.09^{\circ}, 65.56^{\circ}, 67.90^{\circ}, 72.16^{\circ}$ and $75.13^{\circ}$, which correspond to the crystal surfaces (110), (-111), (111), (202), (- 202), (020), (202), (-113), (-311), (220), (311) and (004), respectively. Green CuO particles have monoclinic crystalline structure with ICDD number of 01-089-5897. It has the following lattice parameters: $a=4.686486, b=3.421156, c=5.129263, a=90^{\circ}, \beta=99.413^{\circ}$, 
$Y=90^{\circ}$, and d-spacing value of $2.52761 \AA$. Some additional X-ray diffraction peaks was observed in the powdered $C$. gigantea leaf sample pattern which demonstrated the $\mathrm{CuO}$ nanocomposite being well encapsulated and interacted with natural compounds such as carbon and calcium. These natural compounds could further accelerate antimicrobial activity of $\mathrm{CuO}$ nanoparticles synergistically $[54,55,56]$. The crystallite size of CuO nanoparticles was estimated from the XRD pattern using the Scherer's Equation at highest FWHM peak (Table 2).

The FT-IR analysis was performed to investigate participation of phytochemical compounds in stabilising and reducing green CuO nanoparticles (Fig. 2(b)). A sharp peak at $3438 \mathrm{~cm}^{-1}$ was assigned to $0-\mathrm{H}$ stretching polyphenols (flavonoids). The peaks between $1633 \mathrm{~cm}^{-1} \mathrm{and}^{1765 \mathrm{~cm}^{-1}}$ were assigned to carbonyl group. The absorption peaks at $1385 \mathrm{~cm}^{-1}$ was assigned to vibration mode of esters. Besides absorption peaks between 1110 and $1115 \mathrm{~cm}^{-1}$ belongs to biomolecules of $C$. gigantea leaves extract [57, 58]. The low reported absorption peak at $540 \mathrm{~cm}^{-1}$ is characteristic of CuO group [59, 60].

The UV-Vis absorbance spectra of $C$. gigantea extract and green CuO sample were illustrated in Fig. 2(c). C. gigantea extract was referred as a control solution which does show two prominent absorbance peaks in UV spectrum at $206 \mathrm{~nm}$ (carbonyl compounds) and $269 \mathrm{~nm}$ (phenolic compounds) [61]. Solution with $\mathrm{CuO}$ nanocomposites illustrated a sharp distinct absorbance peak at $233 \mathrm{~nm}$ which belongs to natural carbon [62]. The produced nanoparticles can be identified by the appearance of small band in their respective spectra which was around $307 \mathrm{~nm}$ for CuO-500C nanocomposite [57].

\subsection{Minimum inhibitory concentration/minimum bactericidal concentration}

The wound associated pathogens are a significant global public health threat with serious wound care and management incurring huge economic costs. $S$. aureus, E. coli, P. aeruginosa, K. pneumoniae and MRSA are the prevailing microbial pathogens that occur in patients with open colonised wounds. Grampositive $S$. aureus bacteria are among the most common pathogens associated with open wound infections [63]. Overall results prove that high concentrated green $\mathrm{CuO} / \mathrm{C} / \mathrm{Ca}$ nanocomposites show more enhanced biocidal activity against various wound pathogens. The preliminary MIC results of CuO-400C exhibit that CuO nanoparticles possess considerable inhibition effect on the $S$. aureus colony counts. The MIC for the CuO- $400 \mathrm{C}$ is $5 \mathrm{mg} / \mathrm{mL}$ for $S$. aureus. At a dosage of $10 \mathrm{mg} / \mathrm{mL}$, the result does not show any antibacterial activity (figure S1(b)), where MBC cannot be achieved at this amount. The antimicrobial activity of CuO-500C is more pronounced than that of CuO-400C, and the MIC/MBC against $S$. aureus is $5 \mathrm{mg} / \mathrm{mL} / 20 \mathrm{mg} / \mathrm{mL}$ (figure S1). Our MIC/MBC results have shown that the $\mathrm{CuO}-400 \mathrm{C}$ nanoparticles produced at low annealing temperature is less effective in killing microbes at low dosage compared with the Cu0-500C sample due to reduced SSA [64]. The strong antimicrobial effect of Cu0-500C sample was attributed to the smaller size and the oval shape which is produced at high calcination temperature. The surface reactivity increases due to the size and the shape of the particles. Previously, Azam et al. (2012) revealed that the small $\mathrm{CuO}$ particles synthesised at $400^{\circ} \mathrm{C}$ have a zone of inhibition radii twice that of particles produced at $700^{\circ} \mathrm{C}$ and that the zone of inhibition decreases with increasing annealing temperature from $400^{\circ} \mathrm{C}$ to $700^{\circ} \mathrm{C}$ [44]. N. Nasihatsheno (2019) identified that the calcination temperature affects the size and the shape of the final products and that the variation in the reaction temperature from $400^{\circ} \mathrm{C}$ to $600^{\circ} \mathrm{C}$ leads to different particle sizes and morphologies of $\mathrm{CuO}$ nanoparticles [65]. Sung Woo Oh et al. (2007) pinpoint in their research that the crystallite size of CuO increases until the calcination temperature reaches $500^{\circ} \mathrm{C}$ and that no significant change in crystallite size is observed at high calcination temperatures $\left(>500^{\circ} \mathrm{C}\right)$ [66]. Furthermore, the $\mathrm{CuO}$ samples prepared at annealing temperatures of $300^{\circ} \mathrm{C}$ and $400^{\circ} \mathrm{C}$ exhibit similar morphological features (e.g. size and shape), but those prepared at $500^{\circ} \mathrm{C}$ exhibit different morphological changes [66].

So, in next set of experiment the antimicrobial performance of CuO-500C sample against non-MDR Gram-negative and MDR pathogens were discussed. The tolerance level based on MBC/MIC shows that the tested strains such as $E$. coli, $P$. aeruginosa and MRSA are not likely sensitive to bactericidal agents. Table 3 illustrates the tested non-MDR and MDR strain. It is evident from Table 3, S. aureus and K. pneumoniae is more susceptible to CuO-500C nanocomposite compare to other tested pathogens. This study recommends that killing mechanisms of CuO/C/Ca nanocomposite towards different species of pathogens should be further investigated.

Table 3

$\mathrm{MIC}$ and $\mathrm{MBC}$ of green $\mathrm{CuO}-500 \mathrm{C}$ sample against various pathogen associated with open wound infections

\begin{tabular}{|llll|}
\hline \multicolumn{4}{c}{ associated with open wound infections } \\
\hline Strain & MIC $(\mathrm{mg} / \mathrm{mL})$ & MBC $(\mathrm{mg} / \mathrm{mL})$ & MBC/MIC \\
\hline S. aureus 29213 & 5 & 20 & 4 \\
\hline E. coli 25922 & 0.625 & 5 & 8 \\
\hline P. aeruginosa 27853 & 0.15625 & 10 & 64 \\
\hline K. pneumoniae 700603 & 1.25 & 5 & 4 \\
\hline MRSA 38591 & 0.3125 & 2.5 & 8 \\
\hline
\end{tabular}

Observation on S. aureus bacterial survival for green CuO-500C and commercial CuO samples at concentration of $10 \mathrm{mg} / \mathrm{mL}$ and $20 \mathrm{mg} / \mathrm{mL}$ under fluorescent visible light were captured after $24 \mathrm{~h}$ incubation. After $24 \mathrm{~h}$ of exposure (figure S2 (b)), green CuO-500C sample had a higher activity in the light rather than the dark (figure S1 (c)), except for the commercial $\mathrm{CuO}$ that had no effect on bacterial reduction.

From here it can be concluded that, $\mathrm{CuO}-500 \mathrm{C}$ which has smaller size and uniform oval shape stand as most potential antimicrobial agent than CuO-400C sample. It also has been identified that the strong antimicrobial effectiveness of green CuO-500C sample under fluorescent light illumination is most likely due to oxidative stress caused by ROS which was activated through photocatalytic reaction [60].

\subsection{Time-kill assay}


The time-dependent bactericidal activity of optimized green CuO-500C sample were determined against $S$. aureus. The outcomes of the experiment are shown in Figs. 3, and S3. A significant reduction of $\leq 2.5 \log _{10}$ in the bacterial colonies proportionally with time were observed for CuO green sample. A reduction in viable count from $4.3 \log _{10}$ to $2.5 \log _{10}$ is captured after $6 \mathrm{~h}$ and complete killing at $12 \mathrm{~h}$. Results demonstrate that a high dosage of Cu0-500 (i.e. $20 \mathrm{mg} / \mathrm{mL}$ ) are required to eliminate $100 \%$ bacterial counts within $12 \mathrm{~h}$. The untreated bacterial strains show no reduction in colony counts even after 24 $\mathrm{h}$ of incubation period. As captured in the time-kill analysis, a significant reduction of non-MDR Gram-positive $S$. aureus colonies were achieved at $6 \mathrm{~h}$ exposure.

\subsection{Inhibition of biofilm formation}

The bacterial biofilm formation was studied using method of crystal violet assay. CuO-500C sample exhibited significant reduction of OD when compared to the negative control sample (Fig. 4). Results showed that the CuO-500C sample was found to markedly inhibit biofilm formed by $S$. aureus. The antimicrobial action of green $\mathrm{CuO}$ nanoparticles might be generally falls within killing mechanisms from free metal oxide ions release and generation of reactive $\mathrm{O}$ species $\left(\mathrm{ROS} ; \cdot \mathrm{O}^{2-}, \cdot \mathrm{OH}^{-}, \mathrm{Cu}^{2+}\right.$ and $\left.\mathrm{Ca}^{2+}\right)[14]$. Further investigation on metal ions release $\left(\mathrm{Cu}^{2+}\right.$ and $\left.\mathrm{Ca}^{2+}\right)$ is recommended.

\subsection{Kirby-Bauer disc diffusion test}

The antimicrobial activities of green CuO-500C and commercial CuO samples at two different concentration $(2.5 \mathrm{mg} / \mathrm{mL}$ and $10 \mathrm{mg} / \mathrm{mL})$ and C. gigantea leaves extract were examined on $S$. aureus. The ZOI reveals that CuO-500C sample was effective towards Gram-positive pathogen when increasing the concentration amount from $2.5 \mathrm{mg} / \mathrm{mL}$ to $10 \mathrm{mg} / \mathrm{mL}$. The previous MIC/MBC results agrees with the finding in this study, in which the CuO nanoparticles antimicrobial effectiveness are concentration-dependent (Table 4 and figure S4). In accordance with Kirby-Bauer disc diffusion findings, the enhanced antimicrobial activity was seen for green CuO-500C sample at $10 \mathrm{mg} / \mathrm{mL}$ when compared with other samples. It might be attributed to rise in more free metal oxides ions and ROS at highest concentration of green nanoparticles.

Table 4

ZOI (mm) of green CuO nanoparticles against $S$. aureus

\begin{tabular}{|lll|}
\hline Green sample & ZOI $(\mathrm{mm})$ at $2.5 \mathrm{mg} / \mathrm{mL}$ & ZOI $(\mathrm{mm})$ at $10 \mathrm{mg} / \mathrm{mL}$ \\
\hline Green CuO-400C & 6 & 7 \\
\hline Green CuO-500C & 6 & 7.33 \\
\hline Commercial CuO & 6 & 6.17 \\
\hline C. gigantea & 6.33 & 6.33 \\
\hline Negative control & 6 & 6 \\
\hline Positive control & 10 & \\
\hline
\end{tabular}

\subsection{Photocatalytic activity of CuO nanoparticles for degradation of methylene blue (MB)}

The photodegradation efficiency of CuO-500C nanoparticles has been studied on the degradation of MB aqueous solution (Fig. 5). The color of the MB slightly decreased after 1 hour at normal room temperature condition and a sharp absorbance peak at wavelength of $665 \mathrm{~nm}$ was dropped significantly. Our methylene blue photocatalytic experiment demonstrated that the green synthesised CuO nanoparticles were found more active for the degradation of $\mathrm{MB}$ in a relatively long interval of time which is about 1 month. It might be attributed to the slow and steady release of free radicals at normal room temperature condition. The performance of $73.33 \%$ for MB color removal was reached at 1-month duration (Table 5), which indicated that natural carbon and calcium wrapped CuO-500C nanoparticles could prolong the release time of free radicals in steady manner for long-term antimicrobial application and create stable environment that might provide biocompatible advantage [67]. It's also believed that overproduced hydroxyl radicals in short duration of time has reactive and hazardous free radicals which causes disturbance to wound-healing related cells and fibroblast [68]. Successful control on steady and slow release of free radicals such as $\cdot \mathrm{O}^{2-}$ and $\cdot \mathrm{OH}^{-}$from this green synthesised nanoparticles might present with biocompatible properties towards human cells and can accelerate wound healing properties [69]. Besides of that, the green synthesised CuO-500C nanoparticles also might be a promising antibacterial photocatalytic agent for wound dressing application.

Table 5

The absorbency of MB during photodegradation activity

\begin{tabular}{|llllll|}
\hline Exposure time (h) & $\mathbf{0}$ & $\mathbf{1}$ & $\mathbf{2}$ & $\mathbf{3}$ & $\begin{array}{l}\mathbf{7 4 4} \\
\text { (1-month) }\end{array}$ \\
\hline MB absorbency at 665 nm & 0.285 & 0.261 & 0.233 & 0.223 & 0.076 \\
\hline Degradation ratio (\%) & 0 & 8.42 & 18.25 & 21.75 & 73.33 \\
\hline
\end{tabular}

\section{Conclusions}

This study reveals the potential of bioderived carbon and calcium decorated on synthesized copper oxide nanocomposite (Cu0-500C) as antimicrobial agent against non-MDR and MDR wound associated pathogens. This bactericidal agent works effectively in concentration-dependent manner and demonstrates

Page 8/16 
strong biofilm inhibition properties against Gram-positive non-MDR strain. The control on steady and slow release of free radicals from this green synthesised nanoparticles might be beneficial biocompatible advantage that can accelerate wound healing properties. Further understanding on photodegradation efficiency of $\mathrm{CuO}-500 \mathrm{C}$ nanoparticles under irradiation of direct sun light or ultra-violet light is needed especially on $\mathrm{ROS}$ release $\left(\cdot \mathrm{O}^{2-}\right.$ and $\cdot \mathrm{OH}^{-}$) profile.

\section{Abbreviations}

C. gigantea: Calotropis gigantea, CuO: copper oxide, C: carbon, Ca: calcium, ROS: reactive oxygen species, SSA: specific surface area, MIC: minimum inhibitory concentration, MBC: minimum bactericidal concentration, XRD: X-ray diffraction, MDR: multi-drug resistant, E. coli: Escherichia coli, $K$. pneumoniae: Klebsiella pneumoniae, S. aureus: Staphylococcus aureus, P. aeruginosa: Pseudomonas aeruginosa, MRSA: Methicillin-resistant Staphylococcus aureus and MB: methylene blue

\section{Declarations}

\section{Ethics approval and consent to participate}

Not applicable.

\section{Acknowledgements}

The authors would like to thank Universiti Sains Malaysia for sponsoring this work under Research University Grant (RUI) -1001/CIPPT/8012338. The support of all the technical staff of Advanced Medical and Dental Institute and School of Materials and Mineral Resources Engineering, Universiti Sains Malaysia, Pulau Pinang, Malaysia, in the characterization of the sample is also acknowledged.

\section{Funding}

This research was funded by the Research University Grant (RUI) -1001/CIPPT/8012338 from Universiti Sains Malaysia.

\section{Consent for publication}

Not applicable.

\section{Availability of data and materials}

The datasets generated and/or analysed during the current study are not publicly available due to the patent application for methods of making and using of copper oxide nanocomposites formed by green synthesis but are available from the corresponding author on reasonable request.

\section{Competing interests}

The authors declare no conflict of interest.

\section{Authors' contributions}

G Ambarasan Govindasamy carried out the green sample preparation, sample characterization and the antibacterial assays, included bacterial preparation, MIC, MBC, time kill-assay, biofilm inhibition tests and Kirby-Bauer disc diffusion method. Nor Hazliana Harun and Srimala Sreekantan assist in the procedures. Rabiatul Basria S. M. N. Mydin is the principal investigator contributes in the experimental design, writing process and gave final approval of this paper for publication. All authors have given approval to the final version of the manuscript.

\section{Authors' information}

G Ambarasan Govindasamy - Email: gambarasan@student.usm.my; ORCID iD: 0000-0002-9263-5083

Rabiatul Basria S. M. N. Mydin - Email: rabiatulbasria@usm.my; ORCID iD: 0000-0001-8971-8809

Nor Hazliana Harun - Email: hazlianarun@student.usm.my; ORCID iD: 0000-0002-5563-4145

Srimala Sreekantan - Email: srimala@usm.my; ORCID iD: 0000-0001-5125-8683

\section{References}

1. Nussbaum SR, Carter MJ, Fife CE, DaVanzo J, Haught R, Nusgart M, Cartwright D (2018) An Economic Evaluation of the Impact, Cost, and Medicare Policy Implications of Chronic Nonhealing Wounds. Value in Health 21(1):27-32

2. Uckay I, Aragon-Sanchez J, Lew D, Lipsky BA (2015) Diabetic Foot Infections: What have we learned in the last 30 years? International Journal of Infectious Diseases 40:81-91

3. September J, Geffen L, Manning K, Naicker P, Faro C, Mendelson M, Wasserman S (2019) Colonisation with pathogenic drug-resistant bacteria and Clostridioides difficile among residents of residential care facilities in Cape Town, South Africa: a cross-sectional prevalence study. Antimicrobial 
Resistance Infection Control 8:180

4. Wang M, Wei H, Zhao Y, Shang L, Di L, Lyu C, Liu J (2019) Analysis of multidrug-resistant bacteria in 3223 patients with hospital-acquired infections (HAl) from a tertiary general hospital in China. Bosn J Basic Med Sci 19(1):86-93

5. Hamzah AMC, Yeo CC, Puah SM, Chua KH, Chew CH (2019) Staphylococcus aureus Infections in Malaysia: A Review of Antimicrobial Resistance and Characteristics of the Clinical Isolates, 1990-2017. Antibiotics 8:(128)

6. Wong SY, Manikam R, Muniandy S (2015) Prevalence and antibiotic susceptibility of bacteria from acute and chronic wounds in Malaysian subjects. J Infect Dev Ctries 9(9):936-944

7. Mohammed A, Seid ME, Gebrecherkos T, Tiruneh M, Moges F (2017) Bacterial Isolates and Their Antimicrobial Susceptibility Patterns of Wound Infections among Inpatients and Outpatients Attending the University of Gondar Referral Hospital, Northwest Ethiopia. International Journal of Microbiology 8953829:1-10

8. Pacios O, Blasco L, Bleriot I, Fernandez-Garcia L, Bardanca MG, Ambroa A, Lopez M, Bou G, Tomas M (2020) Strategies to Combat Multidrug-Resistant and Persistent Infectious Diseases. Antibiotics. 9(65)

9. Sharma JK, Akhtar M, Ameen S, Srivastava S, P. and Singh G (2015) Green synthesis of CuO nanoparticles with leaf extract of Calotropis gigantea and its dye-sensitized solar cells applications. J Alloy Compd 632:321-325

10. Sorbiun M, Mehr ES, Ramazani A, Fardood ST (2018) Green Synthesis of Zinc Oxide and Copper Oxide Nanoparticles Using Aqueous Extract of Oak Fruit Hull (Jaft) and Comparing Their Photocatalytic Degradation of Basic Violet 3. International Journal of Environmental Research 12:29-37

11. Aminuzzaman M, Kei LM, Liang WH (2017) Green synthesis of copper oxide (CuO) nanoparticles using banana peel extract and their photocatalytic activities. AIP Conference Proceedings. 1828: 020016

12. Altikatoglu M, Attar A, Erci F, Cristache CM, Isildak I (2017) GREEN SYNTHESIS OF COPPER OXIDE NANOPARTICLES USING OCIMUM BASILICUM EXTRACT AND THEIR ANTIBACTERIAL ACTIVITY. 26 (12): 7832-7837

13. Naika HR, Lingaraju K, Manjunath K, Kumar D, Nagaraju G, Suresh D, Nagabhushana H, H (2015) Green synthesis of CuO nanoparticles using Gloriosa superba L. extract and their antibacterial activity. Journal of Taibah University for Science 9:7-12

14. Jadhav MS, Kulkarni S, Raikar P, Barretto DA, Vootla SK, Raikar US (2017) Green Biosynthesis of CuO \& Ag-CuO nanoparticles from Malus Domestica leaf extract and evaluation of antibacterial, antioxidant, DNA cleavage activities. New J Chem 42:204-213

15. Narasaiah P, Mandal BK, Sarada NC (2017) Biosynthesis of Copper Oxide nanoparticles from Drypetes sepiaria Leaf extract and their catalytic activity to dye degradation. IOP Conf Series: Materials Science Engineering 263:022012

16. Maria A, Vincent MV, Mookkaiah R, Subramani R, Nadesan K (2020) Catharanthus Roseus Leaf Extract Mediated Facile Green Synthesis of Copper Oxide Nanoparticles and Its Photocatalytic Activity. Chemical Methodologies 4:424-436

17. BERRA D, BENHAOUA LAOUINI,SE, B., OUAHRANI, M. R., BERRANI, D. and RAHAL A (2018) GREEN SYNTHESIS OF COPPER OXIDE NANOPARTICLES BY PHEONIX DACTYLIFERA L LEAVES EXTRACT. Digest Journal of Nanomaterials Biostructures 13(4):1231-1238

18. Sharma D, Thakur N, Vashistt J, Bisht GS (2018) Antibacterial Evaluation of Cuprous Oxide Nanoparticles Synthesized Using Leaf Extract of Callistemon viminalis. Indian Journal of Pharmaceutical Education and Research. 52(3)

19. Apriandanu DOB, Yulizar Y (2019) Tinospora crispa leaves extract for the simple preparation method of CuO nanoparticles and its characterization. Nano-Structures Nano-Objects 20:100401

20. ljaz F, Shahid S, Khan SA, Ahmad W, Zaman S (2017) Green synthesis of copper oxide nanoparticles using Abutilon indicum leaf extract: Antimicrobial, antioxidantand photocatalytic dye degradation activities. Tropical Journal of Pharmaceutical Research 16(4):743-753

21. Tu HL (2019) Biosynthesis, Characterization and Photocatalytic Activity of Copper/Copper Oxide Nanoparticles Produced Using Aqueous Extract of Lemongrass Leaf. Composite Materials 3(1):30-35

22. Qamar H, Rehman S, Chauhan DK, Tiwari AK, Upmanyu V (2020) Green Synthesis, Characterization and Antimicrobial Activity of Copper Oxide Nanomaterial Derived from Momordica charantia. Int J Nanomed 15:2541-2553

23. Singh J, Kumar V, Kim K, Rawat M (2019) Biogenic synthesis of copper oxide nanoparticles using plant extract and its prodigious potential for photocatalytic degradation of dyes. Environ Res 177:108569

24. Sarkar J, Chakraborty N, Chatterjee A, Bhattacharjee A, Dasgupta D, Acharya K (2020) Green Synthesized Copper Oxide Nanoparticles Ameliorate Defence and Antioxidant Enzymes in Lens culinaris. Nanomaterials. 10(312)

25. Velsankar K, Vinothini V, Sudhahar S, Kumar MK, Mohandoss S (2020) Green Synthesis of CuO nanoparticles via Plectranthus amboinicus leaves extract with its characterization on structural, morphological, and biological properties. Applied Nanoscience 10:3953-3971

26. Prasad KS, Patra A, Shruthi G, Chandan S (2017) Aqueous Extract of Saraca indica Leaves in the Synthesis of Copper Oxide Nanoparticles: Finding a Way towards Going Green. Journal of Nanotechnology. 7502610

27. Shi L, Tang P, Zhang W, Zhao Y, Zhang L, Zhang H (2017) Green synthesis of CuO nanoparticles using Cassia auriculata leaf extract and in vitro evaluation of their biocompatibility with rheumatoid arthritis macrophages (RAW 264.7). Tropical Journal of Pharmaceutical Research 16(1):185-192

28. Asemani M, Anarjan N (2019) Green synthesis of copper oxide nanoparticles using Juglans regia leaf extract and assessment of their physico-chemical and biological properties. Green Process Synth 8:557-567

29. Acharyulu NPS, Dubey RS, Swaminadham V, Kollu P, Kalyani RL, Pammi SVN (2014) Green Synthesis of CuO Nanoparticles using Phyllanthus Amarus Leaf Extract and their Antibacterial Activity Against Multidrug Resistance Bacteria. International Journal of Engineering Research \& Technology (IJERT). 3(4): 639 
30. Kumar PPNV, Shameem U, Kollu P, Kalyani RL, Pammi SVN (2015) Green Synthesis of Copper Oxide Nanoparticles Using Aloe vera Leaf Extract and Its Antibacterial Activity Against Fish Bacterial Pathogens. BioNanoSci. 5: 135-139

31. Kumari P, Panda PK, Jha E, Kumari K, Nisha K, Mallick MA, Verma SK (2017) Mechanistic insight to ROS and Apoptosis regulated cytotoxicity inferred by Green synthesized CuO nanoparticles from Calotropis gigantea to Embryonic Zebrafish. Sci Rep 7:16284

32. Hosseinzadeh R, Mohadjerani M, Mesgar S (2017) Green synthesis of copper oxide nanoparticles using aqueous extract of Convolvulus percicus L. as reusable catalysts in cross- coupling reactions and their antibacterial activity. IET Nanobiotechnol 11(6):725-730

33. Chowdhury R, Khan A, Rashid MH (2020) Green synthesis of CuO nanoparticles using Lantana camara flower extract and their potential catalytic activity towards the aza-Michael reactiont. RSC Adv 10:14374

34. Anwaar S, Maqbool Q, Jabeen N, Nazar M, Abbas F, Nawaz B, Hussain T, Hussain SZ (2016) The Effect of Green Synthesized CuO Nanoparticles on Callogenesis and Regeneration of Oryza sativa L. Frontiers in Plant Science. 7(1330)

35. Fardood ST, Ramazani A (2018) Black Tea Extract Mediated Green Synthesis of Copper Oxide Nanoparticles. Journal of Applied Chemical Research 12(2):8-15

36. Santhoshkumar J, Shanmugam V (2020) Green Synthesis of Copper Oxide Nanoparticles from Magnolia Champaca Floral Extract and its Antioxidant \& Toxicity Assay using Danio Rerio. International Journal of Recent Technology and Engineering (IJRTE). 8(5): 5444

37. Sukumar S, Rudrasenan A, Nambiar DP (2020) Green-Synthesized Rice-Shaped Copper Oxide Nanoparticles Using Caesalpinia bonducella Seed Extract and Their Applications. ACS Omega 5:1040-1051

38. Khan TM, Mateen AU (2018) Synthesis of CuO Nanoparticles by using Leaf Extracts of Melia azedarach and Morus nigra and their Antibacterial Activity. Journal of Innovative Sciences 4(2):120

39. Cherian T, Ali K, Saquib Q, Faisal M, Wahab R, Musarrat J (2020) Cymbopogon Citratus Functionalized Green Synthesis of CuO-Nanoparticles: Novel Prospects as Antibacterial and Antibiofilm Agents. Biomolecules. 10(169)

40. Janowska A, Dini V, Oranges T, lannone M, Loggini B, Romanelli M (2019) Atypical Ulcers: Diagnosis and Management. Clinical Interventions in Aging $14: 2137-2143$

41. Han G, Ceilley R (2017) Chronic Wound Healing: A Review of Current Management and Treatments. Adv Ther 34:599-610

42. Djavid GE, Tabaie SM, Tajali SB, Totounchi M, Farhoud A, Fateh M, Ghafghazi M, Koosha M, Taghizadeh S (2020) Application of a collagen matrix dressing on a neuropathic diabetic foot ulcer: a randomised control trial. JOURNAL OF WOUND CARE WUWHS SUPPL EMENT. 29(3)

43. Frykberg RG, Banks J (2015) Challenges in the Treatment of Chronic Wounds. ADVANCES IN WOUND CARE 4(9):560

44. Azam A, Ahmed AS, Oves M, Khan MS, Memic A, A (2012) Size-dependent antimicrobial properties of CuO nanoparticles against Gram-positive and negative bacterial strains. Int J Nanomed 7:3527-3535

45. El Desouky FG, Saadeldin MM, Mahdy MA, Wahab E, S. M. A. and Zawawi E, I. K (2020) Impact of calcination temperature on the structure, optical and photoluminescence properties of Nanocrystalline Cerium oxide thin films. Mater Sci Semicond Process 111:104991

46. Yu J, Yu H, Cheng B, Zhao X, Yu JC, Ho W (2003) The Effect of Calcination Temperature on the Surface Microstructure and Photocatalytic Activity of $\mathrm{TiO}_{2}$ Thin Films Prepared by Liquid Phase Deposition. J Phys Chem B 107:13871-13879

47. Saravanan S, Sivasankar T (2016) Effect of Ultrasound Power and Calcination Temperature on the Sonochemical Synthesis of Copper Oxide Nanoparticles for Textile Dyes Treatment. Environmental Progress Sustainable Energy 35(3):669

48. Jiao Z, Zhou G, Zhang H, Shen Y, Zhang X, Li J, Gao X (2018) Effect of Calcination Temperature on Catalytic Performance of CeCu Oxide in Removal of Quinoline by Wet Hydrogen Peroxide Oxidation from Water. J Braz Chem Soc 29(11):2233-2243

49. Gawade VV, Gavade NL, Shinde HM, Babar SB, Kadam AN, Garadkar KM (2017) Green synthesis of ZnO nanoparticles by using Calotropis procera leaves for the photodegradation of methyl orange. J Mater Sci: Mater Electron 28(18):1-7

50. Harun NH, Mydin SMN, Sreekantan RB, Saharudin S, Basiron KA, Aris N, Zain FWanM, W. N. and Seeni A (2020) Bactericidal Capacity of a Heterogeneous $\mathrm{TiO}_{2} / \mathrm{ZnO}$ Nanocomposite against Multidrug-Resistant and Non-Multidrug-Resistant Bacterial Strains Associated with Nosocomial Infections. ACS Omega 5:12027-12034

51. El-Kased RF, Amer RI, Attia D, Elmazar MM (2017) Honey-based hydrogel: In vitro and comparative In vivo evaluation for burn wound healing. Scientific Reports 7:9692

52. Saharudin KA, Sreekantan S, Basiron N, Khor YL, Harun NH, Mydin SMN, Akil RB, Seeni HM, A. and Vignesh K (2018) Bacteriostatic Activity of LLDPE Nanocomposite Embedded with Sol-Gel Synthesized $\mathrm{TiO}_{2} / \mathrm{ZnO}$ Coupled Oxides at Various Ratios. Polymers 10(878):1-18

53. Lee KX, Shameli K, Miyake M, Kuwano N, Ahmad Khairudin NB, Mohamad SE, Yew YP (2016) Green Synthesis of Gold Nanoparticles Using Aqueous Extract of Garcinia mangostana Fruit Peels. Journal of Nanomaterials 8489094:1-7

54. Mydin RBSMN, Zahidi INM, Ishak NN, Ghazali NSSN, Moshawih S, Siddiquee S (2018) Potential of Calcium Carbonate Nanoparticles for Therapeutic Applications. Mal J Med Health Sci 14(SUPP1):201-206

55. Marquis G, Ramasamy B, Banwarilal S, Munusamy AP (2015) Evaluation of antibacterial activity of plant mediated CaO nanoparticles using cissus quadrangularis extract. Journal of Photochemistry Photobiology 155:28-33

56. Dizaj SM, Mennati A, Jafari S, Khezri K, Adibkia K (2015) Antimicrobial Activity of Carbon-Based Nanoparticles. Adv Pharm Bull 5(1):19-23

57. Siddiqi KS, Husen A (2020) Current status of plant metabolite-based fabrication of copper/copper oxide nanoparticles and their applications: a review. Biomaterials Research. 24 (11) 
58. Bhavyasree PG, Xavier TS (2020) Green synthesis of Copper Oxide/Carbon nanocomposites using the leaf extract of AdhatodavasicaNees, their characterization and antimicrobial activity. Heliyon 6(2):e03323

59. Das P, Ghosh S, Ghosh R, Dam S, Baskey (Sen) M (2018) Madhuca longifolia plant mediated green synthesis of cupric oxide nanoparticles: A promising environmentally sustainable material for wastewater treatment and efficient antibacterial agent. Journal of Photochemistry Photobiology B: Biology 189:66-73

60. Fouda A, Salema SS, Wassel AR, Hamza MF, Shaheen TI (2020) Optimization of green biosynthesized visible light active CuO/ZnO nano-photocatalysts for the degradation of organic methylene blue dye. Heliyon 6:e04896

61. Mongkholrattanasit R, Krystufek J, Wiener J, Studnickova J (2011) Natural Dye from Eucalyptus Leaves and Application for Wool Fabric Dyeing by Using Padding Techniques. Natural Dyes. IntechOpen. 4

62. Son Y, Park S (2018) Green preparation and characterization of graphene oxide/carbon nanotubes loaded carboxymethyl cellulose nanocomposites. Sci Rep 8:17601

63. Dunyach-Remy C, Essebe CN, Sotto A, Lavigne J (2016) Staphylococcus aureus Toxins and Diabetic Foot Ulcers: Role in Pathogenesis and Interest in Diagnosis. Toxins. 8 (209)

64. Damm C, Munstedt H, Rosch A (2008) The Antimicrobial Efficacy of Polyamide 6/Silver-Nano- and Microcomposites. Mater Chem Phys 108:61

65. Nasihatsheno N (2019) Synthesis and Characterization of Nano-Structure Copper Oxide from Two Different Copper (II) Metal-Organic Framework Precursors. Nanochem Res 4(1):94-100

66. Oh SW, Bang HJ, Bae YC, Sun YK (2007) Effect of calcination temperature on morphology, crystallinity and electrochemical properties of nanocrystalline metal oxides $\left(\mathrm{CO}_{3} \mathrm{O}_{4}, \mathrm{CuO}\right.$, and $\left.\mathrm{NiO}\right)$ prepared via ultrasonic spray pyrolysis. J Power Sources 173(1):502-509

67. Yang Z, Hao X, Chen S, Ma Z, Wang W, Wang C, Yue L, Sun H, Shao Q, Murugadoss V, Guo Z (2018) Long-Term Antibacterial Stable Reduced Graphene Oxide Nanocomposites Loaded with Cuprous Oxide Nanoparticles. Journal of Colloidal Interface Science 533:13-23

68. Sung T, Wang Y, Liu K, Chou C, Lai P, Hsieh C (2020) Pholiota nameko Polysaccharides Promotes Cell Proliferation and Migration and Reduces ROS Content in $\mathrm{H}_{2} \mathrm{O}_{2}$-Induced L929 Cells. Antioxidants. 9(65)

69. Fu PP, Xia Q, Hwang H, Ray PC, Yu H (2014) Mechanisms of nanotoxicity: Generation of reactive oxygen species. Journal of food drug analysis 22:6475

\section{Figures}




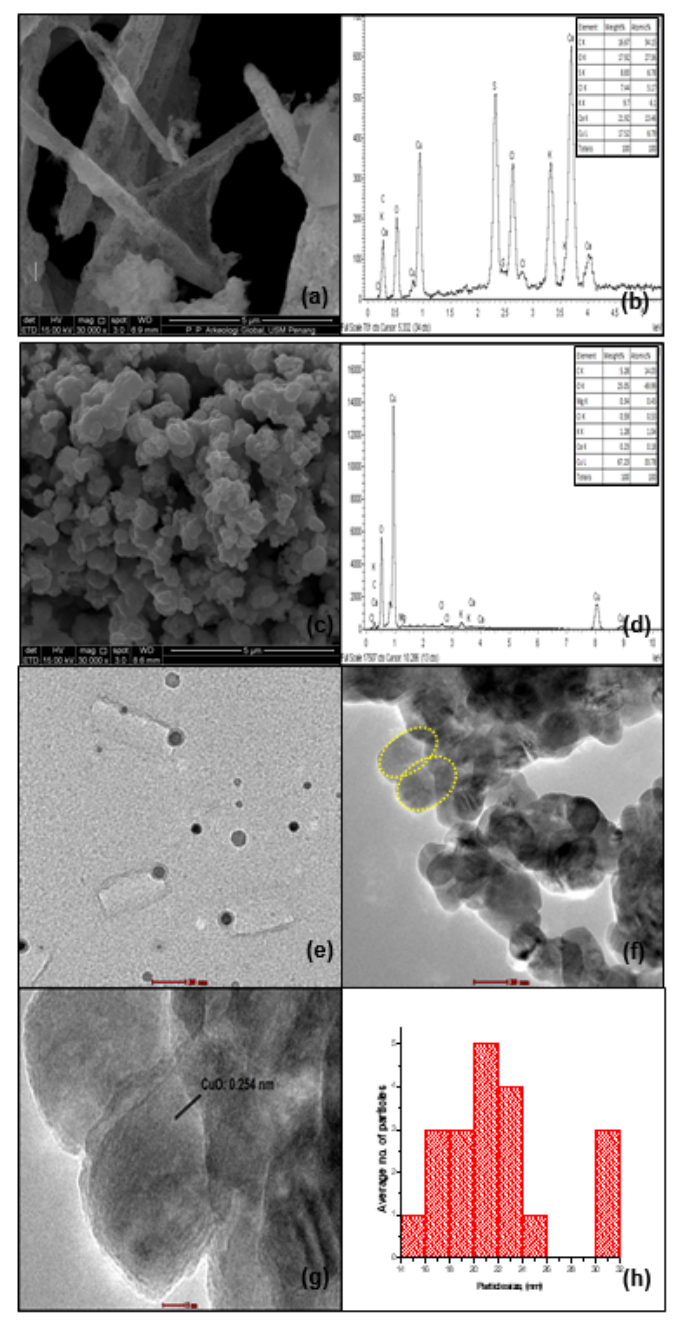

Figure 1

Morphology and green synthesis process of CuO; (a) SEM image of CuO- 400C (5 $\mu \mathrm{m})$, (b) EDAX of CuO-400C, (c) SEM image of CuO-500C (5 $\mu \mathrm{m})$, (d) EDAX of CuO-500C, (e) TEM images of CuO-400C (20 nm), (f) TEM images of CuO-500C (20 nm), (g) TEM lattice fringes of CuO-500C and (h) Histogram of CuO$500 \mathrm{C}$ particle size distribution 

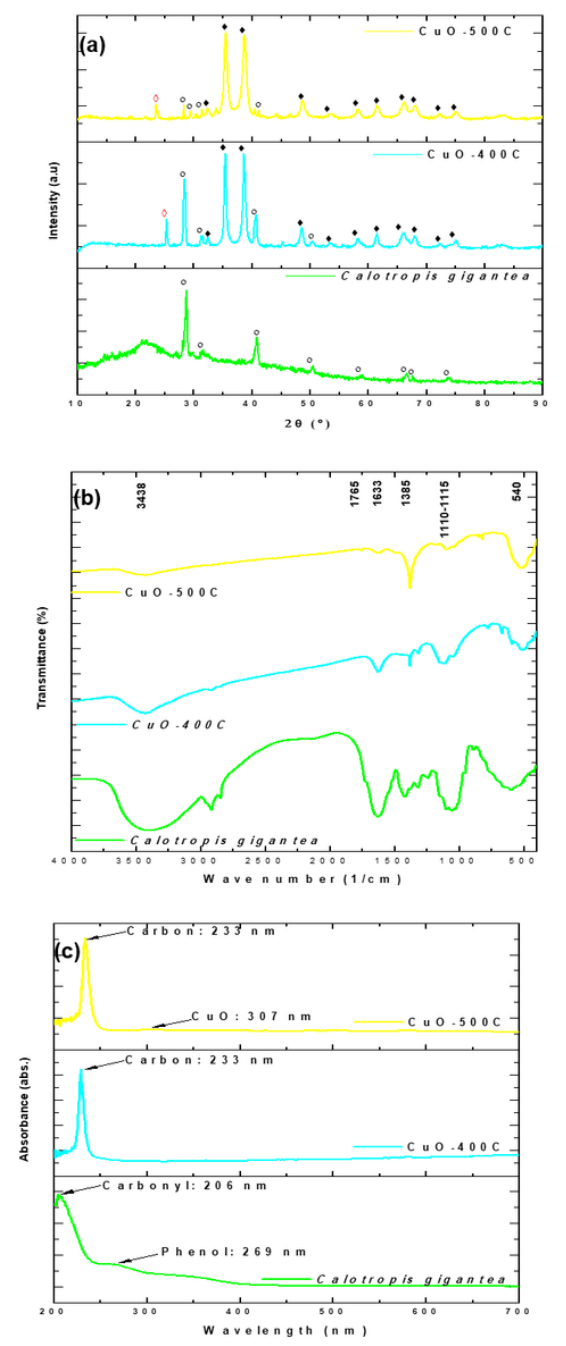

Figure 2

(a) XRD diffraction peaks. [ : C. gigantea leaves, : CuO, : Additional peaks appeared after green synthesis]; (b) FTIR spectra; and (c) UV-Vis absorbance spectra 


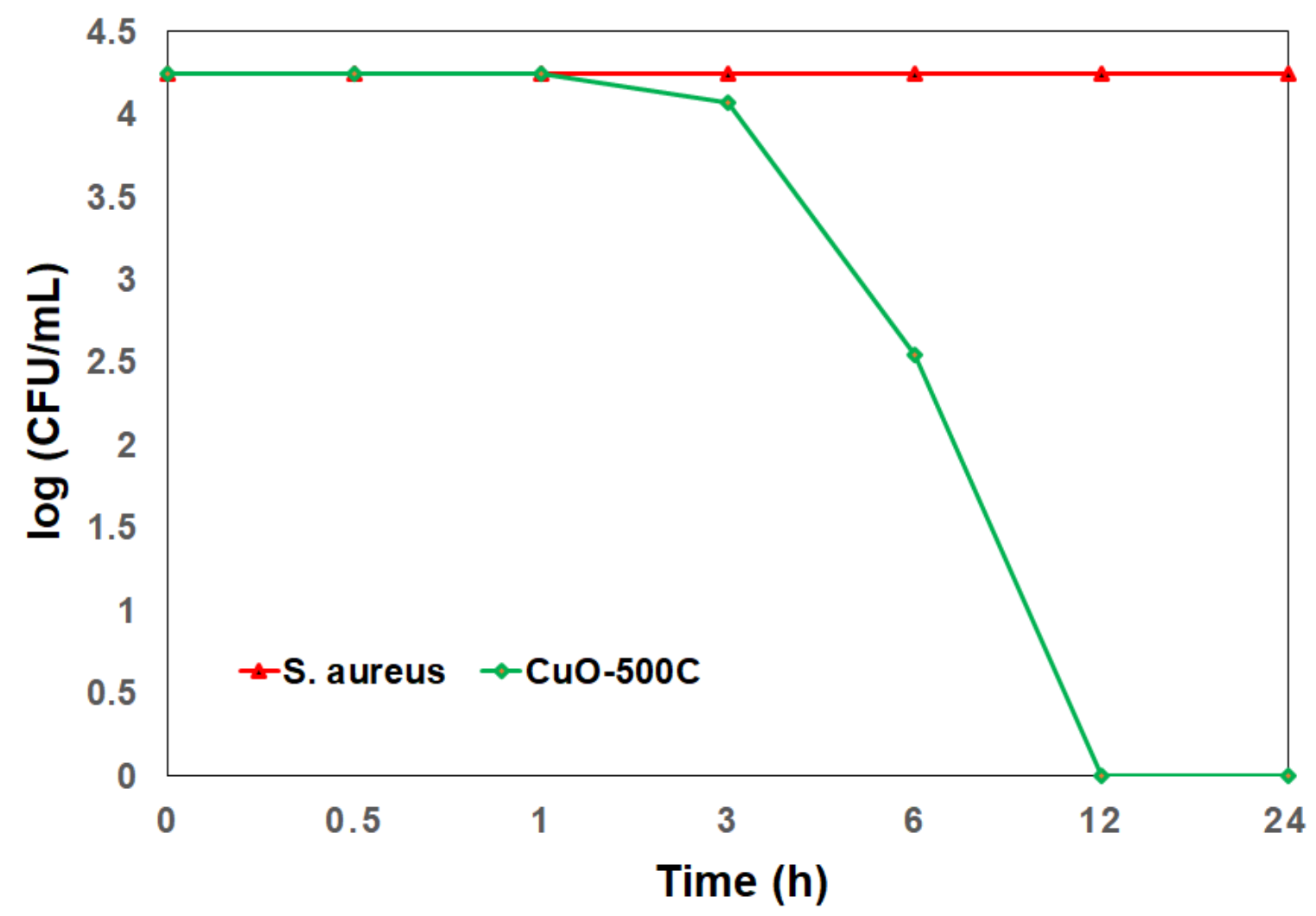

Figure 3

Time-kill curves against S. aureus strains using $20 \mathrm{mg} / \mathrm{mL}$ of CuO- $500 \mathrm{C}$ sample for $0.5 \mathrm{~h}(30 \mathrm{~min}), 3 \mathrm{~h}, 6 \mathrm{~h}, 12 \mathrm{~h}$ and $24 \mathrm{~h}$ treatment periods. These data represent mean $( \pm S D)$ of three replicates.

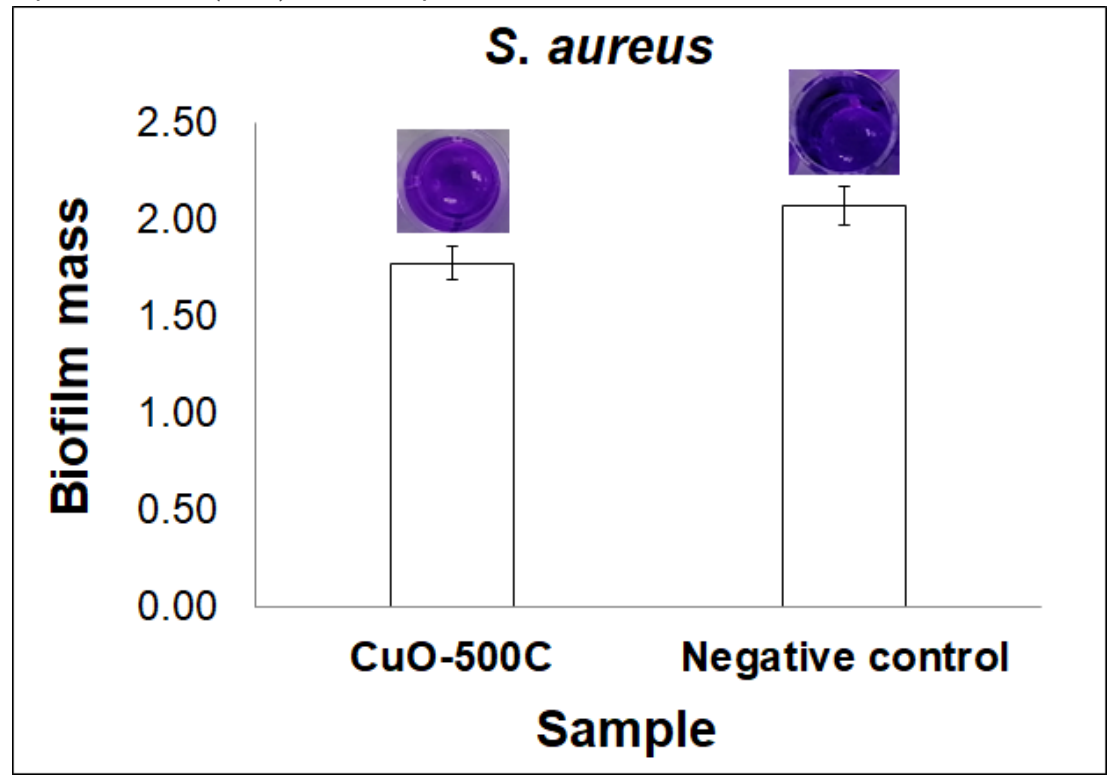

Figure 4

Crystal violet assay to assess the biofilm inhibition activity of samples against pre-growth bacterial strains biofilm for $24 \mathrm{~h}$. These data represent mean $( \pm$ SD) of three replicates. 


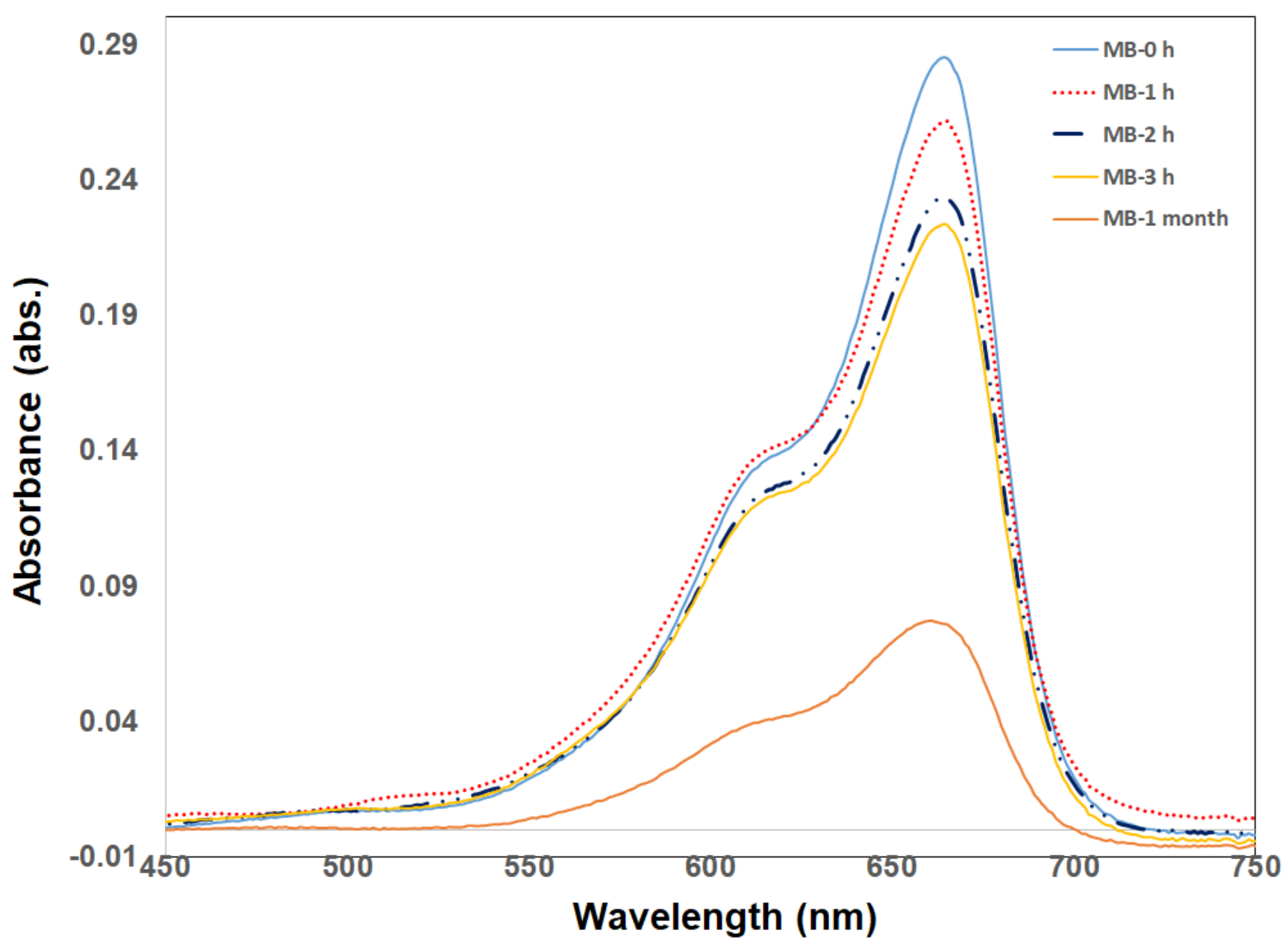

Figure 5

UV-Visible spectra for the degradation of methylene blue (MB) by CuO-500C nanoparticles

\section{Supplementary Files}

This is a list of supplementary files associated with this preprint. Click to download.

- GraphicalAbstractPNG22.1.2021.png

- SupportingInformationGAmbarasan22.1.2021.doc 